WHAT WE MADE 



\title{
WHAT WE MADE
}

Conversations on Art and Social Cooperation

\author{
TOM FINKELPEARL
}


(C) 2013 Duke University Press

All rights reserved

Printed in the United States of America on acid-free paper @ Designed by Jennifer Hill

Typeset in Arno Pro by Tseng Information Systems, Inc.

Library of Congress Cataloging-in-Publication Data appear on the last printed page of this book. 
This book is dedicated to my most inspiring teachers:

Jeff Weiss, middle school science

Nancy Sizer, high school composition

Richard Rorty, undergraduate philosophy

James Rubin, undergraduate art history

Alice Aycock, graduate school sculpture

They were often way off the (narrowly imagined) subject, so each one taught me far more than the curriculum might have predicted. 
